\title{
85682 - LASERTERAPIA ASSOCIADA AO GUARANÁ: UMA ESTRATÉGIA TERAPÊUTICA ALTERNATIVA NA PREVENÇÃO DE LESÕES DE PELE
}

\author{
Pôster - Gerontologia
}

Nathália Cardoso de Afonso Bonotto / Bonotto, NCA / UFSM; Verônica Farina Azzolin / Azzolin, VF / UFSM; Daíse Raquel Maldaner / Maldaner, DR / UFSM; Ivana Beatrice Mânica da Cruz / Cruz, IBM / UFSM; Marta Medeiros Frescura Duarte / Duarte, MFD / UFSM; Fernanda Barbisan / Barbisan, F / UFSM

Introdução: O envelhecimento celular pode ser explicado pela teoria das espécies reativas de oxigênio (EROS). Essa teoria é baseada no envelhecimento induzido por efeitos deletérios na célula causados pelas EROS, as quais são consideradas um pré-requisito para o processo inflamatório e apoptótico. Dessa forma, o estresse oxidativo teria um papel central nos processos de envelhecimento celular da pele fortemente relacionado a queda na síntese de colágeno e elastina por parte dos fibroblastos, assim com o envelhecimento há uma maior propensão ao surgimento de lesões de pele, que são hoje um grave problema de saúde pública no Brasil. Alternativas de prevenção as lesões são relevantes de serem estudadas e podem impactar o cenário social, de saúde e econômico. Objetivo: Avaliar o efeito in vitro da laserterapia de baixa potência associada ao guaraná em fibroblastos humanos envelhecidos. Metodologia: Fibroblastos dérmicos humanos (HFF-1) foram adquiridos comercialmente, cultivados em condições ideias de cultura celular. Inicialmente as células foram envelhecidas através de cultivo, e então expostas a guaraná na concentração de $5 \mu \mathrm{g}$ / mL e após 2 horas ao laser de baixa potência (LBP) usando um Endophoton LLT 0107 KLD® a $660 \mathrm{~nm}$ como fonte de irradiação, potência de saída de $35 \mathrm{~mW}$, frequência $16 \mathrm{~Hz}$, modo de onda contínua pontual, dose administrada de $4 \mathrm{~J} / \mathrm{cm} 2$ com tempo de exposição de $14 \mathrm{~s}$. Após 72 horas de exposição foram analisados marcadores oxidativos (dano ao DNA, dano a lípideos) e níveis proteicos dos fatores de crescimento FGF-1 e KGF relacionados a sintese de colageno e elastina. A análise estatistica através do programa Graph Pad Prism 5.0, por Anova de 2 vias seguida de teste Post-Hoc de Tukey. Foram considerados significativos os resultados com $\mathrm{p}<$ que 0.05 . Resultados: O tratamento combinado com guaraná e LBP diminuiu significativamente a oxidação de lipideos e do DNA, bem como modulou positivamente os níveis de FGF-1 e KGF. Algumas dessas alterações também foram observadas após o tratamento com guaraná ou LBT isoladamente. Conclusões: Apesar das limitações inerentes aos estudos in vitro, estes resultados podem ser considerados significativos, podendo ter relevância tanto na clínica médica como estética, uma vez que esta pode ser uma alternativa importante na prevençaõ de lesões de pele, bem como na questão de rejuvenescimento. Entretanto, mais estudos precisam ser realizados para confirmação destes resultados. 